\title{
INTERAKSIONISME SIMBOLIK APARATUS DAN PEKERJA SEKS DI BALI
}

\author{
I Dewa Ayu S Joni ${ }^{1}$, Ni Nyoman Dewi Pascarani ${ }^{2}$, Tedi Erviantono ${ }^{3}$ \\ ${ }^{1}$ Fakultas Ilmu Sosial dan Ilmu Politik, Universitas Udayana \\ email: ayu_sugiarica@unud.ac.id \\ 2Fakultas Ilmu Sosial dan Ilmu Politik, Universitas Udayana \\ email: pasca.bali@yahoo.com \\ ${ }^{3}$ Fakultas Ilmu Sosial dan Ilmu Politik, Universitas Udayana \\ email: erviantono2@unud.ac.id
}

\begin{abstract}
This article explores a form of symbolic interaction between the formal security apparatus of the State and sex workers in Bali. The study uses qualitative research methods with data collection methods for interviews and observations. Through this type of research traced the efforts of sex workers to communicate in order to negotiate their interests with the power represented by the local government security apparatus (apparatus). Sanders' (2001) and O'Neill's (2001) study shows sex workers are resistant to control. But in this capacity, sex workers have a communication style to negotiate activities with local state officials. Theory used symbolic interactionism from Blumer. In the field data obtained there are two types of meaning in symbolic interactions. Sex worker as a party spreading disease and violation of morality. Even this is used as building the meaning of the moral image of regional leaders. In this symbolic interaction meaning, sex workers with bureaucratic state apparatus are very dependent on social structures in society which depend on social status, involvement in sex trade organizations, and laws or policies related to the regulation of CSWs. Bali as a world tourism destination prioritizes the basic value of the development of cultural tourism and has never once declared it as sex tourism. It's just ironic that Bali is often used as a transit point for the existence of the trafficking industry before they depart overseas. Bali is used as the main transit of commercial sex workers in the women's trafficking network. Although in the interactionism the symbolic meaning of the repression of the state apparatus is still considered to manifest a patriarchal value system that provides more legal sanctions to service providers in this case sex workers, especially women, than their users, namely men.
\end{abstract}

Keyword: symbolic interactionism; sex workers; state apparatus.

\begin{abstract}
ABSTRAK
Artikel ini mendalami bentuk interaksionisme simbolik antara aparat keamanan formal Negara dengan para pekerja seks di Bali. Penelitian menggunakan jenis penelitian kualitatif dengan metode koleksi data wawancara dan observasi. Melalui jenis penelitian ini ditelusuri upaya pekerja seks berkomunikasi guna menegosiasikan kepentingannya dengan kekuasaan yang terepresentasi melalui diri perangkat keamanan (aparatus) pemerintah daerah. Kajian Sanders (2001) dan O'Neill (2001) menunjukkan pekerja seks resisten terhadap aksi penertiban. Namun pada kapasitas ini, pekerja seks memiliki gaya berkomunikasi untuk menegosiasikan aktifitas dengan aparat negara setempat. Teori digunakan interaksionisme simbolik dari Blumer. Pada data lapangan yang diperoleh terdapat dua jenis makna dalam interaksi simbolik. PSK sebagai pihak atau agens persebaran penyakit dan agen pelanggaran moralitas. Hanya saja stigmasi ini digunakan sebagai sarana membangun makna citra
\end{abstract}


moralis pemimpin daerah. Pada makna interaksionisme simbolik ini, pekerja seks dengan aparatus negara birokrasi bergantung pada bangunan sosial di masyarakat yaitu tataran status sosial, seperti keterlibatan mereka pada organisasi perdagangan seks, dan resiko pelanggaran hukum atau kebijakan terkait pengaturan PSK. Bali sebagai destinasi pariwisata dunia mengedepankan dasar nilai pengembangan pariwisata budaya dan sama sekali tidak pernah mendeklarasikan sebagai pariwisata seks. Hanya saja ironisnya Bali seringkali justru dijadikan ajang transit bagi keberadaan industri trafiking sebelum mereka diberangkatkan ke luar negeri. Bali digunakan sebagai transit utama PSK dalam jaringan tindak perdagangan perempuan (women trafiicking). Meski dalam interaksionisme makna simbolik ini, tindakan represi aparatus negara dianggap memanifestasikan tata nilai patriarkhi yang memberikan sanksi hukum pada penyedia jasa dalam hal ini pekerja seks, terutama perempuan, ketimbang penggunanya, yaitu laki-laki.

Kata Kunci: interaksionisme simbolik; pekerja seks; aparatus negara.

\section{PENDAHULUAN}

Kajian terkait keberadaan pekerja seks senantiasa aktual. Pemberitaan terkait penangkapan artis yang diindikasikan terlibat prostitusi online beberapa waktu lalu, memperlihatkan kepada masyarakat sebenarnya upaya Negara dalam penanganan kasus ini tidak pernah tuntas. Merebaknya penertiban kasus-kasus prostitusi pada beberapa sisi masih parsial. Penutupan lokalisasi sudah menjadi aksi klasik para kepala daerah di negara kita yang mengedepankan alasan terjaminnya moralitas masyarakat sekitar dan pencegahan penyakit seksual, meski kenyataannya kontraproduktif (cnnIndonesia, 25 Mei 2018). Alasan lain yang menyebabkan kontrapruduktif adalah keterbatasan pemahaman bahwa aksi prostitusi hanya dijalankan pekerja seks berjenis kelamin perempuan dibandingkan laki-laki atau transgender (Joni, 2018). Pada posisi ini muncul anggapan selama ini bekerjanya aparat dalam kasus prostitusi dianggap pencitraan yang mengukuhkan posisi mereka sebagai sekedar polisi moral (Sindonews, 26 Agustus 2018).

Beberapa riset Sanders (2001) dan O'Neill (2001) memperlihatkan perbincangan tata kelola prostitusi menjadi realitas yang senantiasa berhadapan dengan perbincangan diskursif soal moral dan gangguan publik, sehingga keberadaannya harus berhadapan dengan aparatus. Cara pandang opresif sebagian besar aparatus menganggap pelegalan segala bentuk kegiatan prostitusi berarti merestui negativitas di tengah masyarakat, sehingga penolakannya lebih besar ketimbang pelegalannya. Hanya saja saat pekerja seks komersial vis a vis (berhadapan) dengan aparatus selalu muncul kontestasi dengan beragam kepentingan. Kontestasi ini bisa dikaji melalui teori interaksionisme simbolik, yaitu teori yang memiliki asumsi bahwa manusia membentuk makna melalui proses komunikasi. Teori ini berfokus pada pentingnya konsep diri dan persepsi yang dimiliki iindividu berdasarkan interaksi dengan individu lain.

Pekerja seks penelitian ini adalah pekerja seks berjenis kelamin perempuan serta trans-gender yang ada di Bali. Sedangkan aparatus mengikuti konsep Athusserian yang mengarah pada State Apparatus yang merupakan perangkat negara moden, yaitu polisi, satuan polisi pamong praja. Pertanyaan riset bagaimana pola interaksionisme simbolik antara pekerja seks dengan aparatus di Bali. Penelitian ini memiliki tujuan menganalisis pola interaksionisme simbolik antara aparatus dengan pekerja seks di Bali. 


\section{TINJAUAN PUSTAKA}

Penelitian tentang pola interaksionisme simbolik di kalangan pekerja seks masih terbatas dan banyak didominasi penelitian deskriptif maupun persepsional khusus terkait PSK perempuan beserta faktor pendorong ekonomi maupun aspek legalitasnya. Hal ini seperti penelitian yang dilakukan oleh Caswanto (2016), Mariyadi (2013) serta Saputra (2017). Pada konteks relasinya dengan penelitian ini, terdapat kajian Sanders (2001) dan O'Neill (2001) yang mengkaji tata kelola prostitusi dipengaruhi jaringan pengetahuan kepentingan beserta relasinya. Tata kelola negativitas tidak berjalan tunggal, melainkan terfragmentasi. Desakan sosial atas kebijakan memperlihatkan perbincangan tata kelola prostitusi menjadi realitas yang berhadapan dengan perbincangan diskursif soal moral dan gangguan publik, sehingga advokasi apapun yang mengatasnamakan kesetaraan hak sipil untuk pelegalannya di parlemen dianggap tidak relevan dan senantiasa ditolak.

Pada situasi sama, Weitzer (2009) menyebut cara pandang opresif sebagian besar politisi menganggap pelegalan prostitusi berarti merestui pemerintah membiarkan tindak kekerasan perempuan, kejahatan terorganisasi perdagangan anak dan manusia. Politisi cenderung mengakomodasi tuntutan kepanikan moral yang disuarakan kekuatan penyeru moralitas individual, organisasi yang mengatasnamakan gerakan berbasis perbaikan moralitas oleh masyarakat dan media massa, sehingga pertimbangan atas penolakannya jauh lebih besar ketimbang pelegalannya.

Fragmentasi wacana diatas menunjukkan bahwa aktifitas prostitusi sangat dekat dengan bentuk bentuk interaksi yang sifatnya simbolik. Sifat interaksi simbolik ini, modelnya di setiap negara berbeda dan salah satunya dipengaruhi iklim sistem sosial dan politik yang sedang berlangsung. Negara-negara Eropa penganut sosial demokrasi, misalnya, dalam kebijakan, sosial, politik dan ekonomi harus berkontestasi dengan ragam kekuatan, baik negara auxiliary state maupun kekuatan eksternal negara seperti jaringan aktifis pekerja. Studi atas model ini dikaji antara lain oleh Mattson (2016), Hubbard, Matthews \& Scoular (2008), dengan memperlihatkan berjalannya kebijakan sosial tata kelola prostitusi di negara-negara Eropa. Mereka menunjukkan kebijakan di masing-masing negara dengan sistem sosial berbeda, arus dominan dimainkan petinggi NGO internasional dan peneliti lembaga riset yang dibiayai pemerintah. Termasuk pula hadirnya jaringan pekerja seks dan aktifis pekerja seks yang berinisiatif mentransformasikan kebijakan prostitusi yang mengatasnamakan hak asasi manusia pada pembahasan parlemen di negara-negara Eropa (Banurea, 2013).

Hal ini memberikan penjelas, respon negara terkait kebijakan tata kelola prostitusi diterjemahkan berbeda, seperti, berbasis larangan di Swedia, penghapusan di Inggris, pelegalan penuh di Belanda atau pelegalan terbatas di Yunani. Penerjemahan atas sifat legalitas kebijakan tata kelola prostitusi berelasi dengan persoalan bagaimana negara mengakui hak-hak sosial warganegaranya (social citizenship). Kebijakan tata kelola prostitusi pada negara-negara dengan social democratic citizenship, corporatist social citizenship dan liberal-residual social citizenship sangat bergantung pada rentang hubungan terhadap beberapa aspek (Hernes, 1987), seperti kapasitas lobby kalangan feminis liberal mengadvokasi kesetaraan gender dalam pekerjaan, perlindungan perempuan dari tindak kekerasan, antisipasi atas tindak pidana perdagangan orang, posisi negara sebagai wasit yang adil atas kesejahteraan, termasuk pilihan warga negara atas pekerjaan berikut hak sosial yang melekat padanya, hingga ke persoalan perlindungan hukum kepemilikan badan/tubuh individu warga negara.

Pada konteks tertentu, pekerja seks komersial adalah profesi legal dengan standar kerja yang jelas sehingga mereka memiliki hak berkomunitas dalam serikat pekerja termasuk ragam upaya tuntutan penghapusan kriminalisasi atas profesinya tersebut 
(Meulen, 2011). Kebijakan sosial penatakelolaan prostitusi berupa program pemberdayaan PSK, juga turut disorot kelompok kontra kebijakan. Pola interaksi yang dibangun adalah tuntutan tuntutan seputar pemberian bantuan perumahan, modal usaha mandiri, dan jaminan kesehatan, hanya intrumen eksperimental yang terlampau otoritatif dan meniadakan aspek partisipatif dan emosional. Interaksi ini memang sangat bergantung pada aparatus sebagai penerjemahan dari negara.

Pada riset ini aparatus merujuk pada pengaktegorian Althusser dimana mengajukan konsep State Apparatus yang terdiri dari polisi, pengadilan, penjara, dsb. State Aparatus (SA) atau Aparatus Negara (AN) memusatkan pengaruhnya pada wilayah publik serta cara bagaimana institusi-institusi itu berfungsi. Althusser kerap menyebut apapratus negara sebagai aparatus represif negara atau represif state apparatus (RSA) namun juga mengambil bentuk atau pola pola yang lebih baru. Teori interaksionisme simbolik merupakan tindakan sosial yang dilakukan individu dan didorong oleh hasil pemaknaan sosial terhadap lingkungan sekitarnya. Makna sosial diperoleh melalui proses interpretasi dan komunikasi terhadap simbol-simbol di sekitarnya.

Proses interpretasi ini menyertakan simbol yang digunakan untuk berkomunikasi dan menyampaikan pesan pada orang lain. Teori interaksionisme simbolik yang paling populer adalah teori yang dikemukakan Herbert Blumer. Teori interaksionisme simbolik menganalisis masyarakat berdasarkan makna subjektif yang diciptakan individu sebagai basis perilaku dan tindakan sosialnya. Individu diasumsikan bertindak lebih berdasarkan apa yang diyakininya, bukan berdasar pada apa yang secara objektif benar. Apa yang diyakini benar merupakan produk konstruksi sosial yang telah diinterpretasikan dalam konteks atau situasi yang spesifik. Hasil interpretasi ini disebut sebagai definisi situasi. Blumer menuliskan tga prinsip utama teori interaksionisme simbolik. Pertama, kita bertindak dan berperilaku berdasarkan makna yang kita interpretasikan dari perilaku atau tindakan kita. Kedua, makna sosial merupakan hasil konstruksi sosial. Ketiga, penciptaan makna sosial dan pemahaman makna sosial merupakan proses interaktif yang terus berlangsung. Makna sosial biasanya sudah eksis jauh sebelumnya. Proses interaksi bisa melanggengkannya, mengubahnya perlahan, atau menggantinya secara radikal.

Teori interaksionisme simbolik melihat realitas sebagai konstruksi sosial yang dibentuk melalui proses interaksi yang terus berlangsung. Teori ini sering digolongkan sebagai teori mikro sosiologi karena ranah analisisnya sampai pada aspek individu. Terdapat tiga ide dasar interaksi simbolik. Pertama, pikiran (Mind) adalah kemampuan untuk menggunakan simbol yang mempunyai makna sosial yang sama, dimana tiap individu harus mengembangkan pikiran mereka melalui interaksi dengan individu lain. Kedua, diri (Self) adalah kemampuan untuk merefleksikan diri tiap individu dari penilaian sudut pandang atau pendapat orang lain, dan teori interaksionisme simbolis adalah salah satu cabang dalam teori sosiologi yang mengemukakan tentang diri sendiri (The-Self) dan dunia luarnya. Ketiga, masyarakat (Society) adalah jejaring hubungan sosial yang diciptakan, dibangun, dan dikonstruksikan oleh tiap individu ditengah masyarakat, dan tiap individu tersebut terlibat dalam perilaku yang mereka pilih secara aktif dan sukarela, yang pada akhirnya mengantarkan manusia dalam proses pengambilan peran di tengah masyarakatnya

\section{METODE PENELITIAN}

Penelitian ini menggunakan metode deskriptif kualitatif. Metode kualitatif mengikuti prosedur penelitian yang menghasilkan data deskriptif, yaitu berupa kata-kata tertulis dari perilaku yang diamati (Moleong, 2005:16). Penelitian ini diarahkan pada penggambaran obyek penelitian secara holistik (menyeluruh) dengan memanfaatkan dua jenis data, yaitu 
data primer dan data sekunder. Data primer adalah data yang diperoleh melalui wawancara mendalam kepada para PSK perempuan yang terkonsentrasi di Bali serta aparatus yang menangani, seperti satuan polisi (Satpol PP) dan organisasi pemerintah daerah lainnya. Pilihan atas lokasi penelitian ini didasarkan pada konsentrasi para pekerja seks yang menjalani jasa ini kebanyakan berada di kabupaten Denpasar, Singaraja, Karangasem, Badung dan Tabanan (Bali Ekspress, 5 Januari 2018). Data sekunder yaitu data yang diperoleh melalui sumber pustaka, antara lain informasi media cetak/website.

Terdapat dua bahan data pada penelitian ini. Pertama, bahan data primer diperoleh dari wawancara dengan pihak-pihak yang terkait dengan PSK di kabupaten Denpasar, Singaraja, Karangasem, Badung dan Tabanan; serta para aparatusnya (pemerintah daerah). Kedua, bahan data sekunder, antara lain: dokumen yang diperoleh pada pejabat berwenang, serta organisasi masyarakat sipil yang relevan dengan tema penelitian.

Setelah data terkumpul, maka selanjutnya adalah tahapan pengolahan dan analisa data. Pada tahap ini analisis data dilakukan dengan menggunakan teknik deskriptif analisis. Pada tahap ini data-data primer yang berupa hasil wawancara digabungkan dengan datadata sekunder yang berasal dari dokumen pendukung. Masing-masing data yang diolah harus diverifikasi dan dicross-check satu sama lain sehingga dalam proses analisis hanya data yang memiliki relevansi kebutuhan penelitianlah yang akan dipakai.

\section{HASIL DAN PEMBAHASAN}

Pada riset yang dilakukan ini terdapat temuan bahwa aparatus dominan yang berinteraksi dengan pekerja seks di Bali meliputi aparat pemerintahan lokal seperti Sapol PP atau dinas pariwisata kabupaten atau kota. Interaksionisme simbolik sangat bergantung pada makna simbol yang diberikan diantara keduanya. Makna simbol ini sifatnya dinamis dan selalu mengalami pergeseran. Kehadiran industri prostitusi dalam turisme senantiasa mengalami pergerakan relatif sehingga memunculkan cultural diversifikasi yang terserap dari berbagai macam pengaruh dan termanifestasi dalam simbol yang beragam.

Praktek prostitusi di dalamnya mengandung makna terkait seksualitas. Seks adalah interaksi dua manusia bersifat mendasar serta diikat berbagai peraturan dan struktur yang melembaga. Ia tidak hanya sekedar hubungan kuasa antara laki-laki dan perempuan, melainkan cerminan berbagai makna simbol yang terbangun dari interaksi bersama masyarakat, kelompok agama, adat, serta berbagai lembaga negara sebagai aparatus yang menyertainya (Olong, 2007:16). Beragam simbol ini bisa berwujud pada makna positif maupun negatif, baik yang mengandung handicap atau stigmatisasi. Untuk membingkai makna simbolik dari proses interaksionisme ini maka konsepsi Blumer menyediakan operasionalisasinya. Blumer dalam konsepnya membangun interaksi simbolik pekerja seks dengan lingkungannya, termasuk aparatus seksualitas, menjadi beberapa bagian, yaitu tekstual dan sosial.

Makna simbolik yang terbangun pada interaksi ini adalah tubuh sebagai realitas keseharian yang tidak pernah netral atau sekedar fisiogis semata. Melainkan persoalan yang disebut Synnot melekat erat dengan hubungan yang masing-masing bagiannya dikonstruksi simbolisme kultural, publik dan privat, positif dan negatif, kepentingan politik atau ekonomi, seksual, atau dominasi moral yang sarat kontroversi. Interaksi antara pekerja seks dengan aparatus menjadi pertarungan kontruksi makna dengan berbagai cara dan proses disertai beragam atribut. Konstruksi makna ini bergantung sepenuhnya pada siapa dan dimana interaksi tersebut terjadi dan dimaknai. Makna ini terus menerus diproduksi guna mendukung kekuasaan yang termanifestasi di wacana masing-masing kelompok. 
Wacana berkaitan erat dengan relasi kuasa dimana interaksi antara pekerja seks dengan aparatus adalah perangkat yang tidak saja menjamin kepatuhan atau cara penundukan yang berbentuk aturan atas warga negara semata. Kekuasaan lebih kepada strategi dan praktik sosial yang senantiasa menyertakan pergeseran makna diantara keduanya. Makna interaksionise simbolik ini meminjam terminologi Blumer dimana interaksi tidak hanya terbatas pada kelompok tertentu yang memiliki kekuasaan termasuk klaim-klaim kebenaran yang dibangunnya. Makna simbolik juga dilahirkan kelompok tertindas yang kondisinya disembunyikan atau tersembunyi. Bangunan relasi kuasa simbolik beroperasinya menyebar di setiap level kehidupan secara produktif serta turut membentuk, memperkokoh, atau justru memperlemah pondasi bekerjanya pekerja seks dalam dunia prostitusi.

Pada interaksionisme persebaran penyakit dan pelanggaran moralitas menjadi lebih dominan. Pelanggaran moralitas mendominasi makna bagi aparatus negara untuk tetap senantiasa merepresi pekerja seks di Bali. Dalam pola interaksi atau komunikasi diantara kedua belah pihak (pekerja seks dan aparatus) yang terjadi pekerja seks tidak memiliki kemampuan menolak atau mengadvokasi dirinya. Mereka lebih banyak menerima atas tindak represi aparatus birokrasi dengan pemberian biaya pemulangan dan pesangon untuk membuka usaha bagi pekerja seks adalah beban pembiayaan yang senantiasa dianggarkan secara rutin di dalam APBD setiap tahunnya (Wawancara Anak Agung; Wawancara I Wayan).

Interaksi simbolik yang sangat terlihat oleh publik adalah penutupan, pemblokiran atau penyegelan lokalisasi prostitusi. Aksi - aksi ini seringkali dijadikan komunikasi prolitik strategis berupa simbol pencitraan berjalannya program-program moralis para kepala daerah setempat. Menariknya, interaksi simbolik yang dibangun antara aparatus dengan pekerja seks di kabupaten Badung tidak hanya berhenti dalam kapasitas represi moral. Pekerja seks lebih dimaknakan pada interaksi antara individu dengan negara sebagai warga yang harus disejahterakan. Melalui program kesejahteraan krama (warga) Badung, para pekerja seks ini diberikan jaminan pengentasan dari industri prostitusi menjadi usahawan mandiri, termasuk jaminan warga dari lahir, manula, hingga pemberian santunan kematian. Hal inipun digunakan sebagai membangun makna citra moralis pemimpin daerah yang mensubstitusikan pekerja seks dalam logika kepantasan kesejahteraan ekonomi atau program pengalihan, pemberdayaan usaha ekonomi produktif, serta beragam pemberdayaan sejenisnya, senafas dengan upaya pengentasan ekonomi yang digaungkan di tingkat nasional maupun daerah.

Pada kapasitas interaksi yang dibangunnya, makna simbolik pemberdayaan dengan pemberian modal ekonomi masih dimaknakan sebagai solusi ideal memutus mata rantai industri jasa seksualitas. Hanya saja kini logika tersebut bergeser, tidak lagi menjadi kebenaran tunggal yang diyakini seratus persen sanggup menyelesaiakan persoalan kehadiran industri jasa seksualitas. Awalnya, pro kontra pendapat yang dijadikan pembenar atas pengetahuan ini adalah narasi sukses kebijakan Walikota Surabaya menangani penutupan lokalisasi Dolly (Wawancara Putu Eni). Namun disisi berbeda, terdapat pula mindset kesadaran akan keterancaman kesehatan terutama persebaran endemi HIV AIDS yang memiliki urgensi lebih mendesak ketimbang sekedar alasan penegakan moralitas.

Beberapa birokrat berkeyakinan bahwa upaya pembubaran atau penyegalan justru mempersulit upaya pendeteksian persebaran endemi HIV AIDS yang sebelumnya terlokalisir menjadi menyebar dan tak terkontrol. Interaksi simbolik lebih memporsikan pekerja seks sebagai ancaman terhadap HIV AIDS dan memiliki pemaknaan simbolik atas ketidaktuntasan penanganan industri jasa seksualitas. Terungkap pada salah satu wawancara dengan informan birokrat dinas sosial, bahwa di tahun anggaran 2016 masih 
terdapat pekerja seks yang terjaring razia. Jumlahnya sekitar 10 orang dengan kelompok usia produktif 20 tahun ke atas. Hanya saja di tahun 2017 tidak ada pekerja seks yang terjaring dalam operasi Satpol PP dan dinas sosial tidak dipasrahi subyek yang harus ditangani, dibina atau dipulangkan. Dari kondisi ini anggaran khusus pos ini masih utuh dan dianggap pekerja seks sudah tertib meski mereka (birokrasi) tidak menelusuri secara lebih jauh peluang atas ruang lain yang digunakannya.

Pada konteks ini pula, apabila di wilayah bersangkutan tidak ada aksi penindakan terhadap pekerja seks (perempuan) selama satu tahun anggaran, maka hal tersebut dianggap bagian cerita sukses atas keberhasilan program pemberdayaan ekonomi, baik yang diberlakukan pada kalangan pekerja seks maupun pemilik (perantara). Meski pada produksi pengetahuan lainnya, muncul anggapan di kalangan birokrat bahwa program-program pemberdayaan pekerja seks sifatnya kosmetikal. Saat dikenakan upaya penertiban, masih terdapat pekerja seks yang cenderung kembali pada profesi lamanya. Interaksi simbolik yang bermakna penertiban sifatnya masih sebatas parsial represif dan sekedar terjebak menelisik dampak yang ditimbulkan sesudahnya. Parsial represif dan hanya mengejar outcome program rutin pemerintahan semata nampak dari wawancara dengan informan birokrat dari Dinas Sosial.

Upaya penertiban abai terhadap penelusuran kondisi substantif beragam dorongan subyektif kehadiran pekerja seks yang justru berpeluang membuka lebar kehadiran industri jasa seksualitas di Bali. Kondisi ini pun akhirnya dipahami oleh kalangan birokrat sebagai bentuk pengetahuan atas hak asasi manusia serta koridor di luar kewenangan pelaksanaan tugas pekerjaan rutin mereka. Sepanjang aktifitas dalam industri jasa pariwisata yang dilakukan tidak menggangu ketentaraman dan keamanan, kesemuanya akan terdapat jaminan untuk tetap bisa melangsungkan aktifitas jasanya (Wawancara NT).

Antara pekerja seks dengan aparatus negara birokrasi relasi kuasanya sangat bergantung pada bangunan sosial di masyarakat dimana mereka berada. Pada interaksi simbolik ini, otonomi pekerja seks bervariasi tergantung pada status sosial, dan persepsi masyarakat yang melingkupinya. Hukum positif Indonesia memang sama sekali tidak memperkenankan adanya industri jasa seksualitas. Industri jasa seksualitas dianalogikan sebagai sebuah tindak kriminalitas yang berhubungan dengan perdagangan orang/perempuan. Perdagangan perempuan menjadi agenda yang sangat dipengaruhi maraknya agenda perdagangan manusia serta pergerakan perempuan lintas batas (migrasi) (Matthews, 2007:12).

Bali sebagai destinasi utama dunia lebih mengedepankan dasar nilai pengembangan pariwisata budaya dan sama sekali tidak pernah mendeklarasikan sebagai pariwisata seks. Hanya saja ironisnya Bali seringkali justru dijadikan ajang transit bagi keberadaan industri trafiking sebelum mereka diberangkatkan ke luar negeri (LBH APIK). Bali digunakan sebagai wilayah transit utama PSK dalam jaringan tindak perdagangan perempuan (women trafiicking). Penyergapan sindikat jaringan perdagangan orang oleh Reskrim Polres Garut yang melibatkan TKW sebagai PSK asal Garut dan Banten tersebar di tempat hiburan wilayah Bali. Dari 20 orang PSK terjaring, sebagian besar tidak mau dipulangkan karena niatannya memang ingin menjadi PSK di Bali. (Tribun, Selasa, 20 Maret 2018).

Bali dianggap memiliki daya tarik bagi persemaian tindak traffiking karena menjamurnya industri spa yang tersebar pada berbagai wilayah di Bali. Daya tarik spa dijadikan kedok sekaligus tujuan dimana didalamnya digunakan oknum industri trafiking sebagai pelatihan sebelum akhirnya mereka dikirim ke luar negeri dengan perantara agen maupun pribadi. ada 12 September 2018, Kepolisian Metro Kota Bandara Soekarno Hatta menangkap Ilham Rairamanda, yang hendak menjual empat anak perempuan dibawah umur sebagai terapis di sebuah spa di Bali. Modus yang dikemukakan polisi, pelaku merekrut anak 
di bawah umur untuk dipekerjakan sebagai tenaga terapis di sebuah spa di Pulau Bali dengan menjanjikan sejumlah uang. Para korban dibawa dari Jakarta menuju Bali dengan penerbangan Lion Air JT42.

Polisi menyita barang bukti telepon genggam, surat palsu berupa surat bukti perekaman KTP elektronik atas nama para korban, lima lembar boarding pass, serta satu bundel screen capture percakapan WhatsApp antara mereka dengan korban. Akibat perbuatan tersangka dikenakan Pasal 76D Jo Pasal 81 ayat 1 dan 2 dan atau Pasal 76E Jo Pasal 82 ayat 1 dan atau Pasal 76F Jo Pasal 83 dan atau Pasal 76I Jo Pasal 88 UU RI Nomor 35 Tahun 2014 ttg Perubahan Atas UU RI Nomor 23 Tahun 2002 tentang Perlindungan Anak dan atau Pasal 2 UU RI Nomor 21 Tahun 2007 ttg Pemberantasan Tindak Pidana Perdagangan Orang dan atau Pasal 263 KUHP dan atau Pasal 266 KUHP. (Jawa Pos, 19 September 2018).

Sebelum diberangkatkan ke luar negeri, pekerja seks mempekerjakan dirinya maupun diperkerjakan para pemilik bisnis seksualitas sebagai tenaga terapis plus beberapa tempat spa yang tersebar di wilayah Bali. Spa dalam makna simbol para birokrat menjadi tempat yang paling dimungkinkan menjadi tempat berlangsungnya industri jasa seksualitas karena didalamnya menyangkut persentuhan tubuh dengan tubuh (Wawancara I Wayan). Selain itu pula akibat undang 0undang tidak menjamin adanya pertumuhan usaha yang semuanya berjin. Hanya beberapa industri spa yang berijin dan terpantau, selebihnya tidak berijin dan tempat ini menjadi persemaian industri jasa seksualitas (Wawancara NT).

Meski dalam interaksionisme makna simbolik tindakan represi aparatus negara tetap dianggap memanifestasikan tata nilai patriarkhi yang lebih memberikan sanksi hukum pada penyedia jasa dalam hal ini pekerja seks, terutama perempuan, ketimbang penggunanya, yaitu laki-laki. Konteks ini menyebabkan kehadiran industri seksualitas senantiasa terbuka lebar dengan ketiadaan kriminalisasi terhadap pengguna sehingga mendorong bertumbuhnya penawaran yang beragam rupa oleh kalangan pekerja seks. Pemaknaan simbolik birokrat yang menyatakan melalui bahasa-bahasa pekerja seks yang membandel, masih senang melakukan profesi pekerja seks, tahu praktik industri ini ada namun sepanjang tidak ada laporan merugikan dari masyarakat maka semuanya adalah konsekuensi tindak pelanggaran hukum yang memang senantiasa akan direpresi namun harus selalu diterima.

Intinya segala bentuk aktifitas ekonomi yang dilakukan pekerja seks tidak pernah bisa dilepaskan dari realitas teraksi simbolik dengan keragaman struktur, termasuk iklim dan kondisi setempat. Bahkan beberapa diantaranya adalah iklim transnasional, struktur sosial-budaya, ekonomi global yang selanjutnya turut dipengaruhi oleh konteks lokal gaya hidup, norma dan nilai seksual, pengalaman rasisme, serta seksisme yang terbentuk sejarah kolonial. Di satu sisi, harus berhadapan dengan tuntutan obyektifikasi seksual, namun di sisi lain memperkenankan terbukanya liberasi seksualitas di kalangan pekerja seks. Hal inilah yang kemudian menjadi pintu masuk kehadiran industri jasa seksualitas yang keduanya senantiasa diskursif pada arena perang yang tidak pernah berkesudahan (Weitzer, 2000 dalam Sanders, Prostituion, Halaman 13).

\section{UCAPAN TERIMA KASIH}

Ucapan terimakasih ditujukan kepada Dekan FISIP Universitas Udayana dan Ketua LPPM Universitas Udayana karena penulisan artikel ini didasarkan dari penggalian data bersumber Hibah Unggulan Program Studi (HUPS) Universitas Udayana Tahun Anggaran 2019. Penulis juga mengucapkan terimakasih kepada narasumber terkait riset ini. 


\section{DAFTAR RUJUKAN}

\section{Buku}

Althusser, Louis. (2015) Ideologi dan Aparatus Ideologi Negara. Indo Progress: Jakarta

Hubbard, Phil, Matthews, Roger, dan Scoular, Jane. (2008) Regulating sex work in the EU: prostitute women and the new spaces of exclusion, dalam Gender, Place and Culture Vol. 15, No. 2, April 2008, 137-152, Routledge.

Hernes, Helga Maria. (1987) The Welfare State and Women Woman Power: Essays in State Feminism. Oslo: Norwegian University Press. Lebih lanjut lihat Mattson, ibid.

Joni, Dewa Ayu Sugiarica (2018) Pemanfaatan Media Online Pekerja Seks Pria di Bali. Laporan Penelitian.

Mattson, Greggor, Christian (2008) Governing Loose Women: Rationalizing European prostitution, 1998-2004. University of California, Berkeley, ProQuest Dissertations Publishing, 2008. 3331707.

Mattson, Greggor. The Cultural Politics of European Prostitution Reform: Governing Loose Women. Palgrave Macmillan: UK.

Moleong. Lexi. J. (2007) Metodologi Penelitian Kualitatif, Edisi Revisi. Bandung: Remaja Rosdakarya.

0’Neill, Maggie \& Pitcher, Jane (2001) Prostitution: Sex Work, Policy \& Politics. Sage: London.

\section{Jurnal}

Banurea, Rima Nusantriani (2013) Jurnal Ilmu Sosial dan Ilmu Politik, Volume 16, Nomor 3, Maret 2013, Berlindung dalam Hak Asasi Manusia: Strategi Pekerja Seks di Eropa untuk Mentransformasi Kebijakan Prostitusi, Halaman 274.

Caswanto, NPM. (2016) repository.unpas.ac.id/4975/3/BAB\%20I.pdf, Tindak Pidana Prostitusi yang Diusahakan dan Disediakan oleh Hotel di Indramayu dalam Perspektif Hukum Pidana di Indonesia.

Duarte, Magdalena (2012) Prostitution and Trafficking in Portugal: Legislation, Policy, and Claims. Sex Res Soc Policy (2012) 9:258-268 D0I 10.1007/s13178-012-0093-2.

Harringtonn, Carol (2011) Asia Pacific Viewpoint, 04/2011, Volume 52, Issue 1, Governing Sex Workers in Timor Leste.

Mariyadi (2013) Journal Volume II. No. 4. Tahun 2013, Persepsi Masyarakat tentang Prostitusi Liar di Keluarahan Sempaja Utara Samarinda.

Sanders, Teela. (2001) Social Policy \& Society (2017) 16:3, 429-441, C Blinded by morality? Prostitution policy in the UK. Capital \& Class, Issue 86; serta Sanders, Teela \& Brown, Kate. 2017. Pragmatic, Progressive, Problematic: Addressing Vulnerability through a Local Street Sex Work Partnership Initiative.

Sauer, Birgit (2004) Taxes, rights and regimentation: discourses on prostitution in Austria. Dalam The Politics of Prostitution: Women's Movements, Democratic States and The Globalisation of Sex Commerce. Dalam Outshoorn. Op.cit. Halaman 41.

Saputra, RP. Dampak Praktek Prostitusi terhadap Pengembangan Pariwisata di Sekitar Parangtritis. eprints.uny.ac.id/53389/5/Ringkasan\%2013413241037.pdf

Umiarso, Elbadiansah (2016) Interaksionisme Simbolik: Dari Era Klasik hingga Modern. Rajagrafindo Press: Jakarta.

Weitzer. Ronald (2009) Journal of Criminology, Vol. 49, No. 1, Morality Politics in Western Australia. The British, Moral Panics-36 Years on Januari 2009, pp. 88-105.

\section{Surat Kabar}

Bali Ekspress, 5 Januari 2018

cnnIndonesia, 25 Mei 2018

Sindonews, 26 Agustus 2018 